Religion and Gender, vol. 2, no. 2 (2012), pp.

375-378

www.religionandgender.org

URN:NBN:NL:UI:10-1-101614

ISSN: $1878-5417$

Publisher: Igitur Publishing (Utrecht)

Copyright: this work is licensed under a Creative

Commons Attribution License (3.0)

\title{
Review of Jan Berry, Ritual Making Women: Shaping Rites for Changing Lives (Gender, Theology and Spirituality Series), London/Oakville: Equinox Publishing 2009, vi + 257 pages, ISBN 978-1-84553-414-1 (hb) \& 978-1-84553-415-1 (pb).
}

By MaheSh Sharma, PANJAB UNIVERSITY, ChandigARH

There is a growing body of literature that maps the deep-seated anguish, hurt and pain that women feel at being excluded from and marginalized in religious rituals - the last bastion of patriarchal control over the normative. The ritual domain is a contested site for the feminist reading of ritual texts and praxis striving to liberate it from the pervasive patriarchal stranglehold. Consequently, there is an energized attempt to 'reclaim' ritual by tailoring it to suit specific feminine requirements. This provides a renewed meaning to the lives of women, and acts therefore as an agency of feminist empowerment. Jan Berry argues in this book that the existing Christian rituals have become irrelevant, impersonal and oppressive, hence necessitating new rituals. Such ritualizing is being done spontaneously, as people did after the death of Princess Diana, or feminists consciously creating interpretative practices in contrast to fixed and repetitive social rites. Such ritual making implicitly challenges the authority of those responsible for creating liturgy, rituals or ceremonies. The author advocates the need to engage with ritual making as a 'constructive' and 
'creative process' (p 230) which is interpreted as 'transformative' and 'liberating' by the participants ( $p 232$ ).

This book, which stems from a doctoral dissertation, furthers our understanding of the mechanics of women's ritual making devised beyond the territory and ambit of church premises and control, and beyond even the therapeutic and pastoral care. The book is organized in nine chapters, of which the first two introduce the theme, rationale and methods, while chapters three to seven specifically contextualize and theorize on five case studies (out of the twelve case studies which have been used in this book), each critical to the central argument. Chapter eight interrogates and reflects upon the theoretical underpinnings of ritual, sacrament and body theology. The last chapter charts the future course for feminist ritual making while 're-imaging rites'.

Jan Berry, herself a church minister and ritual practitioner who participated in and also devised some of the women's rituals discussed in this book, provides a 'thick description' in awareness that interpretation is inbuilt in the selection and retelling of stories ( $p 45$ ). Being an educator, practitioner and researcher, she believes in the 'critical correlation' -moving from practice to theory and back to practice again ( $p$ 57). Hers is an attempt to build a 'strategic' theology that brings the personal into the public domain with the kind of reflexivity that interrogates the 'use of the self' in research for a better retelling of gendered narratives ( $p$ 53). These are 'enacted' narratives (ritual and the accompanying text or interviews/stories) that construct an identity in which feminine bodily processes, emotions and experiences are honoured; in which life-changing transitions (such as loss of job or new job, divorce, completion of dissertation) are celebrated, or cathartic rites devised to overcome loss and grief; and in which patriarchal stereotypes, such as 'submissive carers', are resisted by a liturgy that does not reinforce the social structure but helps in negotiating change.

Symbols, language and space are critical to feminist ritual making. Even though biblical symbols are used, Berry emphasizes that these must be read in the contexts and lived experiences of women. The domestic space, which is private and intimate, replaces the public and formal church premises. The rituals are participatory without any allocated leadership roles, and all 'invited' contribute to and experience their purpose and innovation ( $p$ 109). The ritual space embraces the everyday world in the same manner as an eating place, playing space or workplace, in contradistinction to the remote and impersonal consecrated ritual space or sanctum. There is also an acute awareness of the feminine force, which is

Religion and Gender vol. 2, no. 2 (2012), pp. 375-378 
reinforced by the conscious exclusion of male-oriented language and symbols. For example, even if these rituals lack 'explicitly female language for God' (no goddess rituals are discussed), yet the 'use of male imagery' is consciously and consistently resisted ( $p 118$ ).

The ritual making springs from the community of friendship and shared experience, underlining openness and 'willingness to engage' ( $p$ 175). The ritual sessions are inclusive, performative, transformative particularly in the case of feminine rites of passage - and even confessional. These rituals are particularly empowering and engender solidarity. For instance, the celebration of menarche and menopause, which otherwise go unnoticed, or are spoken about in hushed tones. By highlighting them, the author emphasizes feminine experiences that require unique rites of passage (that are different from men's), which do not find space in the patriarchally controlled and extolled religious sites. Hence, the need to intervene, invent and celebrate women-centred rites. Such an intervention empowers feminist identity while it challenges patriarchal control over the ritual domain. Berry tellingly concludes: 'It is this power of ritual performance to subvert, reconstruct and transform that is at the heart of women's ritualizing' ( $p$ 203).

The author is comfortable in a postmodern framework, particularly the deconstruction of the notions of 'the essential self', which helps her argue that identity is not fixed but 'assumed' and contextual ( $p$ 135). Feminist ritual making, which plays a dominant role in the construction of self, builds upon the narratives that emerge from social interaction which aims at interpreting and shaping women's experience. These stories are integrated into the body of ritual and shared with the larger community. In the process of performance and sharing, a perspective is built, the 'self is negotiated and constructed' ( $p$ 148). Such constructions are multi-layered and take 'new forms as women share' (151), creating a social bond which is essential in negotiating power relations. Clearly, the author draws inspiration from the works of Paul Ricoeur. She also engages with major feminist ritual theorists and with ritual theory in general. Such affinities are not always integrated into her analysis, while, instead, she is rather argumentative. The production of lengthy arguments and frequent quotes, however praiseworthy in a doctoral thesis, leaves one guessing at the line that the author wants to take. In spite of a couple of allusions to goddess communities, it would have been useful to draw insights from (and compare) such ritual communities where women's body processes are ritualized and celebrated. Moreover, not each of Berry's twelve case studies of women who are theologically educated may represent and 
reflect the insights of a large population. Notwithstanding these irritants, the book offers fresh insights in an area where a lot of work needs to be done. It does provide hope for those women who are betrayed by the existing social structures, and suggests new areas and ways in ritual making by which feminist solidarity and empowerment may be constructed. 